\title{
LEVEL OF PRE-MATHEMATICAL IMAGINATIONS OF CHILDREN WITH VISUAL IMPAIRMENT OF PRE-SCHOOL AGE
}

\author{
Andrea Kovácsová, Eliška Třečková, Jitka Vítová
}

\begin{abstract}
The study acquires readers with results of research investigation in the area of arithmetical and geometrical imaginations of children with visual impairment. It compares reached level by them in the area of pre-mathematical imaginations with the level of intact population.
\end{abstract}

\section{Key words}

Child with visual impairment, child in preschool age, pre-mathematical imaginations, arithmetic, geometry.

The world of numbers and shapes ${ }^{1}$ is connected by some of us with the world of plays and amusement, by the others with anxiety, which will recall memory on the time spent over the tasks from mathematics. In real life most of the adults use mathematics quite currently during everyday activities. We can claim that each individual has in greater or smaller measure acquired so called mathematical literacy, under which Blažková (2010) arranges:

- ability to comprehend abstract mathematical concepts,

- ability to comprehend relations among mathematical objects,

- ability to work with mathematical objects,

- ability of mathematisation of real situation,

- ability to exploit the obtained mathematical knowledge in other, new situations,

- application of mathematical knowledge in practical tasks.

An opinion rules among public in general that the above introduced abilities the child acquires as late as at the entry to primary (elementary) school. Maybe that the words of Hejný $(2009$, p. 23) will attribute to the change of the view of the reader on the given problem: "mathematics does not start by counting, just as acquirement of the language does not start with grammar".

1 The term used Hejný and Stehlíková in the book Numerical concept of children. 
If we search the factors, which take part in unsuccessfulness of child in school mathematics, we find several of them Michálková (2001) mentions necessity of a certain level of maturity of the central nerve system, which is an important condition for the acceptance and elaboration of the stimulation from external and even internal environment. As imperfectly equipped and deployment brain or the brain centres could be the cause of a certain deceleration of the development of mathematical abilities.

Reality that the degree of language competences could have influence on the development of difficulties in mathematics, is confirmed by Blažková (2008, p. 38), who informs that ninety percent of problems in mathematics is caused by problems in communication between a child and world around".

Ginsburg, Klein and Starkey (1998) consider mathematical knowledge of children as a result of formal and informal experience. While informal knowledge of mathematics forms outside the school environment and represents problematic solving of the situation with concrete objects, which the child acquires through the interaction with physical and social world already in the period of pre-school age of the child; ${ }^{2}$ formal mathematics represents arithmetic skills (manipulation with systems of written symbols) and concept of children learning at school.

Development of mathematical imaginations on the theoretical level, could be caught with the help of so called models of mathematical thinking, e.g. Gelman and Galliestela (1978) distinguished following stages of development of prenumerical imaginations, which characterized by help of basic principles:

- principle of correspondence one to one is mastered by the most of five years old children, when in counting the sets of elements, the children will incorporate each element just once;

- principle of permanent sequence represents knowledge of numeric sequence, when the child has acquired verbal counting. This ability develops within age of pre-school child from knowledge one, two, three till knowledge one, two, three up to twenty;

2 Hejný (1989) similar to Gelman and Gallistela (1978) indicates that the seeds of numerical concepts in the consciousness of the child has already started to appear around the second year of life, perhaps even earlier and are the result of everyday life experiences of the child. 
- cardinal principle - is mastered by children at the entrance to school. This principle develops later than the principle of correspondence and permanent sequence. In this stage the child realizes at the end of elements counting that the last named number represents total figure of the elements of the set;

- principle of abstractness - the child sums up beside same objects even objects of different shape and size;

- principle of sequence - irreverence - the child, on the base of experience, appreciates invariability of final sum of the objects at the change of sequence.

It is necessary to be aware that the separate stages can overlap in different ways and with regard to individual development of the child they could differ by the course and even time length.

Gruszczyk-Kolezyňská (Zelinková, 2001) mention in the context of school matters so called school readiness for mathematics with which, beside prenumeric imaginations, is closely connected the level of emotional maturity of the child. As another factor, which could not be omitted, influencing successfulness of development of mathematical abilities of the child, we consider the child's effort itself.

Quite another aspect seems to be undervaluation of mathematical knowledge of the children at entry of elementary (primary school). Results of international research revealed fundamentally deeper knowledge of children than their teachers, specialists and even parents supposed. Therefore the authors (Tichá, Hošpesová and Kuřima, 1995) recommend submitting entry didactic test to children and carry out diagnostic interview. The obtained data could become a starting point for individual adjustment of learning plan for individual pupils in the first year of school. The teacher gets possibility of optimal expansion of till now obtained child's mathematical skill and also to develop in natural form child's discovery of the world of mathematics.

\section{Aim of the research}

We were interested, in connection with the framework of educational programme for pre-school and basic education and all the time more frequent trend of school integration, which level of pre-mathematical imagination reach the children with visual impairment in comparison with their intact contemporaries. 


\section{Research sample}

We addressed for cooperation several current nurseries, 3 nurseries for children with visual impairment and teachers of nurseries, who have an integrated child with visual impairment in the class. A total number of 47 children of pre-school age participated in the investigation, who took part in enrolment to the first class of elementary (primary) school this year. The mean age of the intact children was 6.31 years and the mean age of children with visual impairment, from which only four children were integrated to current nursery, was 6.35 (see Table 1 and 2). Eleven children had different level and combination of refractive defect together with amblyopia, two children were after operation of inborn cataract and simultaneously amblyopia was diagnosed in them and two children had diagnosis of refractive defect together with squint. None of the followed children was blind. Five children had beside visual impairment also language deficiency and visited speech therapist, one child had beside visual impairment also ADHD diagnosis and one from the children went during the followed period through diagnostic process, as there was, beside visual impairment, also suspicion on other impairments

Tab. 1: Mean evaluation of all respondents

\begin{tabular}{|l|c|c|c|c|c|}
\hline \multicolumn{1}{|c|}{ children } & number & mean age & $\begin{array}{c}\text { total mean } \\
\text { number of } \\
\text { points }\end{array}$ & $\begin{array}{c}\text { total number } \\
\text { of points in } \\
\text { arithmetic }\end{array}$ & $\begin{array}{c}\text { total number } \\
\text { of points in } \\
\text { geometry }\end{array}$ \\
\hline intact & 23 & 6.31 & 6.95 & 3.7 & 3.26 \\
\hline $\begin{array}{l}\text { with visual } \\
\text { impairment }\end{array}$ & 24 & 6.35 & 8 & 3.79 & 4.21 \\
\hline
\end{tabular}

Tab. 2: Mean evaluation of children with visual impairment

\begin{tabular}{|l|c|c|c|c|c|}
\hline \multicolumn{1}{|c|}{ children } & number & mean age & $\begin{array}{c}\text { total mean } \\
\text { number of } \\
\text { points }\end{array}$ & $\begin{array}{c}\text { total number } \\
\text { of points in } \\
\text { arithmetic }\end{array}$ & $\begin{array}{c}\text { total number } \\
\text { of points in } \\
\text { geometry }\end{array}$ \\
\hline $\begin{array}{l}\text { from nursery } \\
\text { for children } \\
\text { with visual } \\
\text { impairment }\end{array}$ & 20 & 6.24 & 8 & 3.95 & 4.05 \\
\hline integrated & 4 & 6.6 & 8 & 3 & 5 \\
\hline
\end{tabular}




\section{Methods of research}

We used modified test material (Tichá, Hošpesová and Kuřima, 1994), which we adjusted with regard to visual affliction of some children (see enclosure A and B). Standard size of the card with separate tasks was B5. The children with visual impairment had possibility of the choice between the size of paper pictures B5 and A4. Only 3 children from the followed children chose the size of the format A4. Two of them were after operation of inborn cataract. We worked individually with children, always after the submission of the picture, the given task was read to them.

\section{Analysis and interpretation of the results}

Results of the children in the test of mathematics and geometry are demonstrated in the graph No. 1 and 2. While the results in the area of mathematic are comparable in both followed groups (the mean number of points in children with visual impairment was 3.79 and in the intact population 3.7), in the area of geometry were surprisingly more successful children with visual impairment (mean number of points in children with visual impairment was 4.21, in the intact population 3.26) (see Tab. 1,2). Nevertheless from statistical data elaboration, with utilization of Mann and Whitney U-test it follows that among the followed group of the intact children and children with visual impairment are not significant differences in both the tests of mathematics and geometry. In both cases we were forced to accept null hypothesis. It is $\mathrm{H}_{0}$ between reached results in the test from mathematics of children with

Graph No. 1: Histogram of frequency in the test of arithmetic

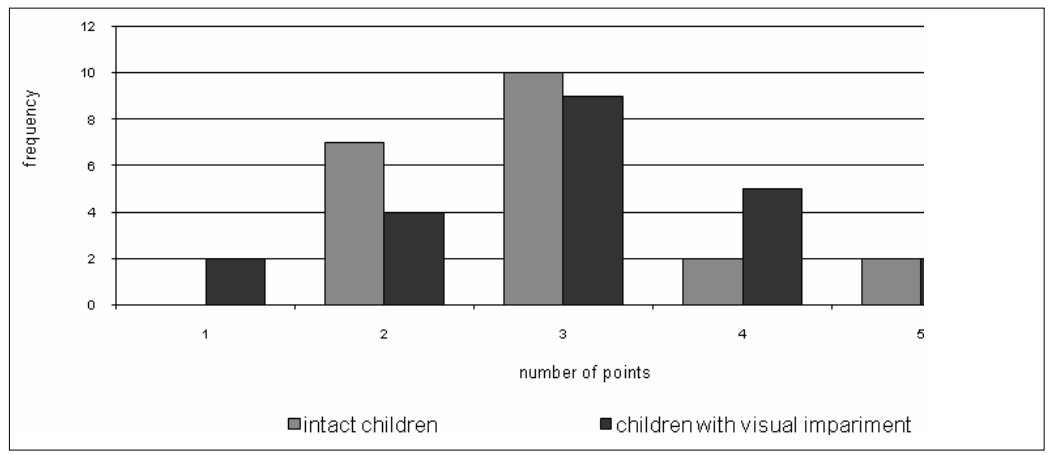


visual impairment and their intact contemporaries are not statistically significant differences and $\mathrm{H} 2_{0}$ between reached results in the test from geometry of children with visual impairment and their intact peers are not statistically significant differences. Results in the separate tests influence the total evaluation of the respondents, how it is demonstrated in the graph No. 3. We can state that the level of pre mathematical imaginations of children with visual impairment in pre-school age is in comparison with their intact contemporaries comparable.

Graph No. 2: Histogram of frequency in the test of geometry

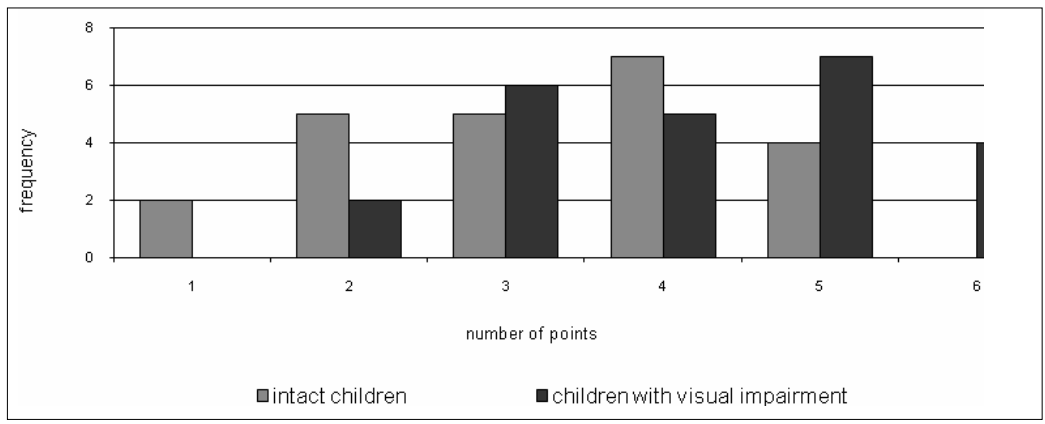

Graph No. 3: Total histogram of frequency in the testss

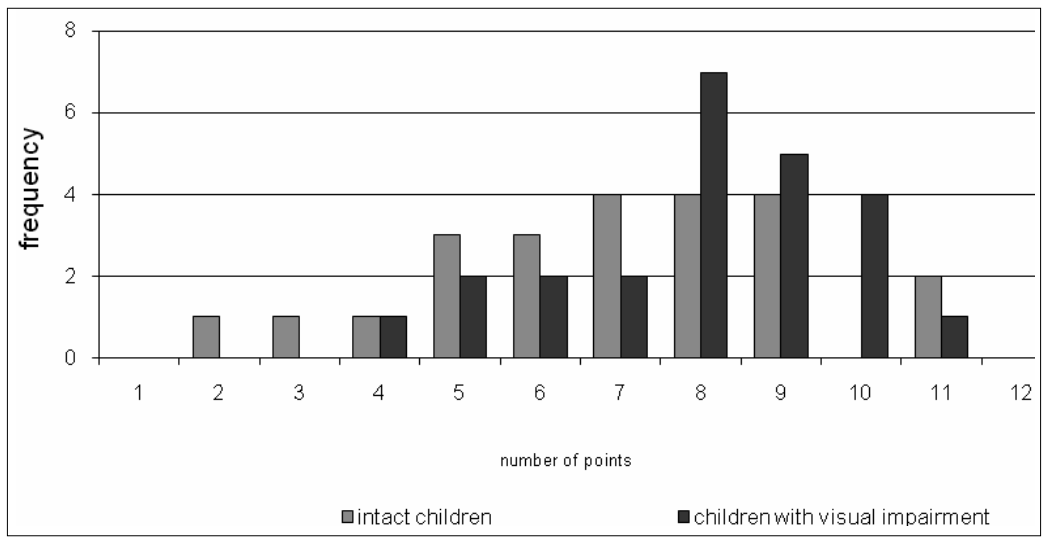


From didactic view it is not possible to follow only successfulness of the children in the tests, but more detailed analysis will be necessary. Therefore we were interested in difficultness of the submitted tasks and their comparison in the followed groups of respondents. In the test of arithmetic the tasks No. 1, 2 and 4 showed to be easy, the tasks No. 3 and 5 were of medium difficulty and the task No. 6 revealed as a difficult one (see Tab. 3) in both groups of respondents. The easy tasks correspond to current ones, to which the child in nursery in the area of mathematics is exposed. The task No. 3 presumes knowledge of numeric row backwards, which is a demanding task for a child of pre-school age. In most cases he/she meets with it in current situations, the task given in words in written form could be demanding on imagination. The task No. 5 presumes acquiring of adding. Some children during solving exchanged (substituted) number of points $(3+4=7)$ with the number of throws $(1+1=2)$. Simultaneously some children had tendency to use fingers for solving the tasks. The task No. 6 finds out the skill of deducting to ten, according to our opinion it demands certain imagination from children. In another words, the child is able to solve the task in general life (he/she has certain experience, it means informal knowledge of mathematics) but has not yet acquire formal knowledge of deducting.

In geometry test only the first task showed to be easy for both followed groups, in which the child should have determined, which pencil is longer. The task No. 3 was easy for children with visual impairment, in which they should have determined the shorter way. Other tasks were of medium difficulty for both the groups (see Tab. 4).

Tab. 3: Difficultness of the task in the test of arithmetics

\begin{tabular}{|l|c|c|}
\hline & intact contemporaries & $\begin{array}{c}\text { children with visual } \\
\text { impairment }\end{array}$ \\
\hline question No.1 (house) & $\mathrm{Q}=0$ & $\mathrm{Q}=0$ \\
\hline question No. 2 (girls) & $\mathrm{Q}=8.7$ & $\mathrm{Q}=12.5$ \\
\hline question No. 3 (space ship) & $\mathrm{Q}=43.48$ & $\mathrm{Q}=50$ \\
\hline question No. 4 (circles) & $\mathrm{Q}=8.7$ & $\mathrm{Q}=12.5$ \\
\hline question No. 5 (automat) & $\mathrm{Q}=78.26$ & $\mathrm{Q}=62.5$ \\
\hline question No. 6 (glasses) & $\mathrm{Q}=91.30$ & $\mathrm{Q}=83.3$ \\
\hline
\end{tabular}


Tab. 4: Difficultness of the task in the test of geometry

\begin{tabular}{|l|c|c|}
\hline & intact contemporaries & $\begin{array}{c}\text { children with visual } \\
\text { impairment }\end{array}$ \\
\hline question No.1 (pencil) & $\mathrm{Q}=0$ & $\mathrm{Q}=0$ \\
\hline question No. 2 (square) & $\mathrm{Q}=52.17$ & $\mathrm{Q}=29.2$ \\
\hline question No. 3 (way) & $\mathrm{Q}=26.09$ & $\mathrm{Q}=12.5$ \\
\hline question No. 4 (juice) & $\mathrm{Q}=60.87$ & $\mathrm{Q}=25$ \\
\hline question No. 5 (construction) & $\mathrm{Q}=60.87$ & $\mathrm{Q}=45.83$ \\
\hline question No. 6 (cars) & $\mathrm{Q}=73.91$ & $\mathrm{Q}=66.66$ \\
\hline
\end{tabular}

About possible causes of higher successfulness of the children with visual impairment in geometry we can only speculate in this moment. With regard to the fact that number of children in both groups is comparable and the same as their age, it is necessary to seek causes somewhere else. We can find possible explanation in the system and content of education in nurseries for children with visual impairment, where is, beside other, decreased number of children in class compared with current nurseries. It enables to teachers to approach a child individually and respect his/her topical needs. The aim of special education care is to reduce or eliminate the consequences of visual impairment, to secure optimal development of these children and prepare them for entry to elementary (primary) school.

It seems that children with binocular sight used in solving of geometry tasks their experience obtained in nurseries during the exercises for sight stimulation and pleoptico-orthoptic exercises (connection of points in space, cutting along the line, string of beads, maze, recognize ten differences). Most of the pupils spared a thought during geometry tasks, carefully examined the picture and only then answered.

The results of submitted research investigation in the area of mathematical education of children with visual impairment invites us to further research activities, to creation of work sheets and methodical materials utilizable by teachers in nurseries. 
Enclosure A test from mathematic

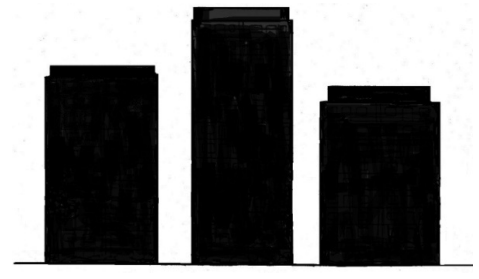

1. There is a row of houses in the picture. Which house is the highest?
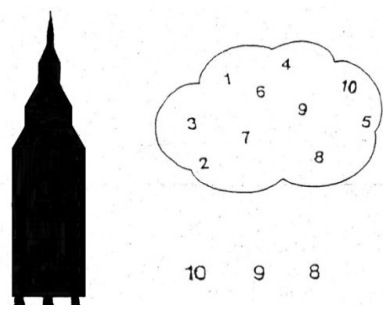

$10 \quad 9 \quad 8$

3. A space ship starts in the picture.

The start is counted down backwards: $10,9,8$.

Which is the next number?
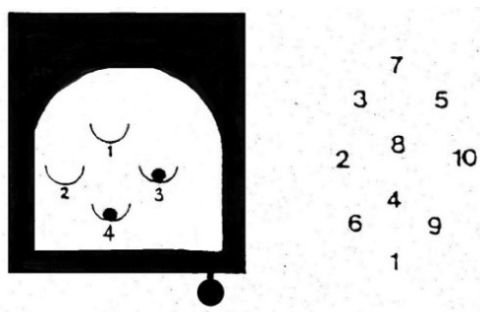

5. Tom got a new toy, an automatic one. He shot and obtained 3 and 4 points. How many points he has together?

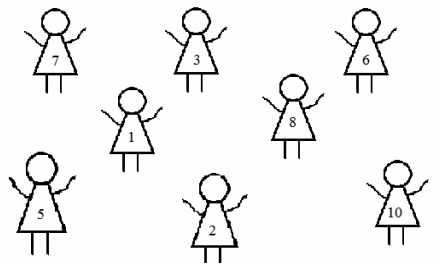

2. There are children in the picture. Where is the girl with number 5 ?

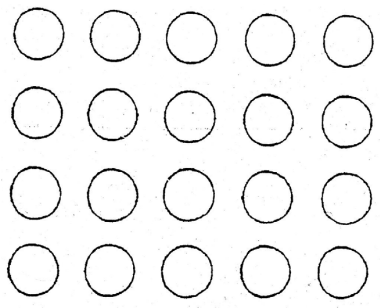

4. Colour 9 circles.

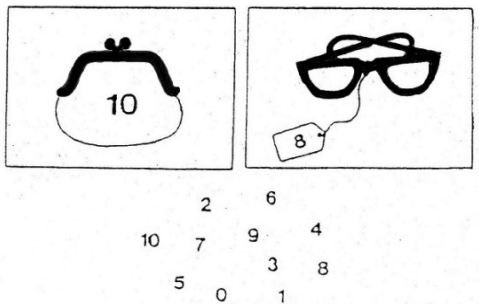

6. Eve has 10 crowns.

She bought paper glasses for carnival for 8 crowns.

How much crowns remained to her? 
Enclosure A test from geometry
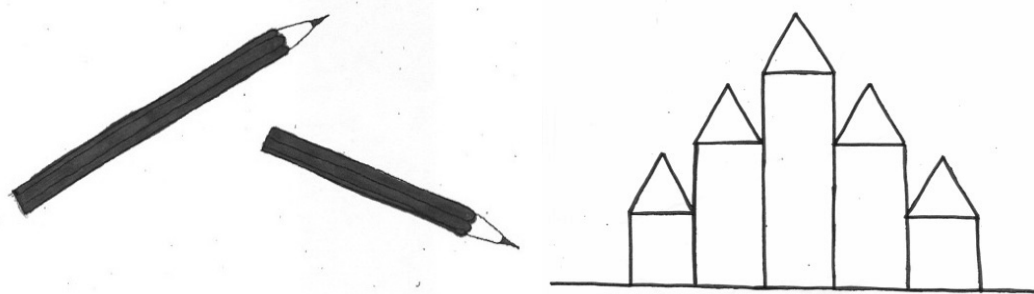

1. Which pencil is shorter?

2. Show me a square in the picture

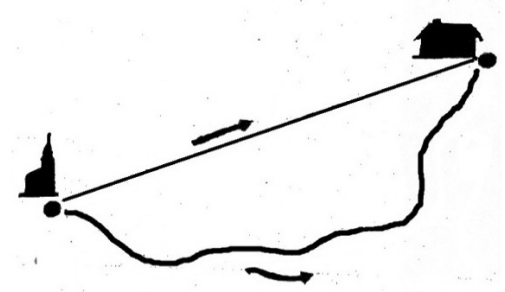

3. Which way is shorter?
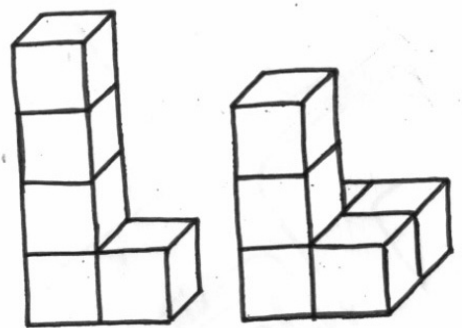

5. The boys constructed two towers. Where is more cubes?

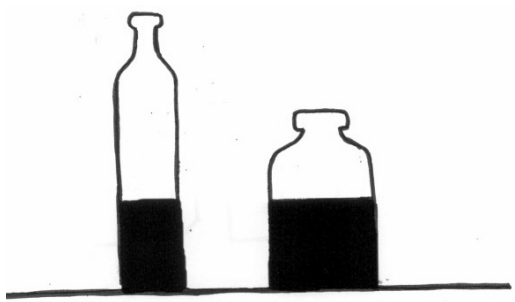

4. In which bottle is more juice?

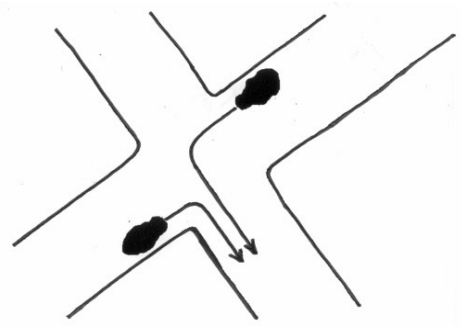

6. Which car turns to right? 


\section{References}

BLAŽKOVÁ, R. Komunikační bariéry v matematice u dětí s poruchami učení. In KLENKOVÁ, J., VÍTKOVÁ, M. (eds.) Vzdělávání žáků s narušenou komunikačni schopností. Brno: Paido, 2008, s. 38-44. ISBN 978-80-7315-167-6.

BLAŽKOVÁ, R. Rozvoj matematických pojmů a představ u dětí předškolního věku. Elpotál, Brno: Masarykova Univerzita, 2010. ISSN 1802-128X.

FINKOVÁ, D., RŮŽIČKOVÁ, V., STEJSKALOVÁ, K. Edukační proces u osob se zrakovým postižením. Olomouc: Univerzita Palackého, 2010.

FINKOVÁ, D., RŮŽIČKOVÁ, V., STEJSKALOVÁ, K. Dítě se zrakovým postižením v raném a predškolním věku. Olomouc: Univerzita Palackého, 2010.

GELMAN, R., GALLISTEL, C. The Child's Understanding of Number. Cambridge: Harvard University Press. 1978.

GINSBURG, H., P., KLEIN, A., STARKEY, P. The Development of Children's Mathematical Knowledge: Connecting Research with Practice, In SIEGEL, I., E., RENNINGER, K., A. Handbook of Child Psychology. New York: Wiley, 1998.

HEJNÝ, M., KUŘINA, F. Dítě, škola a matematika. Praha: Portál, 2009. ISBN 978-80-7367-397-0.

HEJNÝ, M. - STEHLÍKOVÁ, N. Císelné predstavy dètí. Praha: Univerzita Karlova, 1999. ISBN 80-86039-98-6.

MICHALOVÁ, Z. Vývojová hlediska rozvoje matematických schopností $\mathrm{v}$ předškolním věku a jejich dopad pro počáteční výuku matematiky ve škole, Speciální pedagogika, 2001, č. 5, Praha: Pedagogická fakulta UK. ISSN 1211-2720.

TICHÁ, M., HOŠPESOVÁ, A., KUŘIMA, F. Jaké jsou matematické zkušenosti našich dětí při vstupu do školy? Obecná škola, 1995, roč. 1, č. 4.

TICHÁ, M., HOŠPESOVÁ, A., KUŘIMA, F. Jaké jsou geometrické zkušenosti dětí na počátku školní docházky? Obecná škola, 1996, roč. 2, č. 7.

ZELINKOVÁ, O. Pedagogická diagnostika a individuální vzdělávací program. Praha: Portál, 2001. ISBN 80-7178-544-X.

\section{Contact}

Mgr. Jitka Vítová, Ph.D.

Institute of Primary and Pre-primary Education

Faculty of Education, University Hradec Králové

Rokitanského 62 
50003 Hradec Králové

jitka.vitova@uhk.cz

Andrea Kovácsová

Institute of Primary And Pre-primary Education

Faculty of Education, University Hradec Králové

Rokitanského 62

50003 Hradec Králové

andrea.kovacsova@uhk.cz

Eliška Třečková

Institute of Primary And Pre-primary Education

Faculty of Education, University Hradec Králové

Rokitanského 62

50003 Hradec Králové

eliska.treckova@uhk.cz 